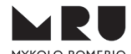

MYKOLO ROMERIO
UNIVERSITETAS

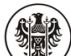

Uniwersytet Wrocławski
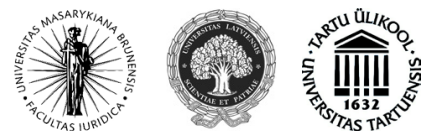

ISSN 1392-6195 (print) ISSN 2029-2058 (online) JURISPRUDENCIJA JURISPRUDENCE 2014, 21(1), p. 578-598.

\title{
THE UNJUST EXERCISE OF EMERGENCY POWERS IN BANGLADESH AND THEIR CONSEQUENT IMPACT ON THE FUNDAMENTAL RIGHTS: A CRITICAL APPRAISAL
}

\author{
M. Ehteshamul Bari \\ Macquarie Law School \\ Macquarie University \\ NSW 2109, Australia \\ E-mail: muhammad.bari@mq.edu.au
}

Submitted on 31 March, 2014; accepted 25 May, 2014

doi:10.13165/JUR-14-21-2-12

\section{Introduction}

It is a common feature of almost every democratic constitution of the world to contain detailed provisions concerning proclamation of emergency to tide over ${ }^{1}$ an actual or imminent threat to the life of nation by war, external aggression, armed rebellion, internal disturbance, natural catastrophes and breakdown in the economy. In fact, the power to proclaim an emergency, which must generally be used as a last resort $^{2}$, may be considered as the state's constitutional or legal right to self-defence comparable with the individual's right to self-defence under the penal law. ${ }^{3}$

1 States of Emergency - Their Impact on Human Rights: A Comparative Study by the International Commission of Jurists. Geneva: International Commission of Jurists, 1983, p. 177, 190.

2 Ibid., p. 451.

3 Bonner, D. Emergency Powers in Peacetime. London: Sweet \& Maxwell, 1985, p. 2.

Jurisprudencija/Jurisprudence

(C) Mykolo Romerio universitetas, 2014

(C) Mykolas Romeris University, 2014
ISSN 1392-6195 (print), ISSN 2029-2058 (online) http://www.mruni.eu/lt/mokslo_darbai/jurisprudencija/ http://www.mruni.eu/en/mokslo_darbai/jurisprudencija/ 
States of emergency are encountered with surprising frequency throughout the world. ${ }^{4}$ One of the immediate consequences of the proclamation of an emergency is the suspension of the right to apply to the designated courts for the enforcement of all, the majority or some of the fundamental rights. The extraordinary measure of suspension of the remedies for enforcement of some of the fundamental rights of the citizens is justified on the ground that fundamental rights of the citizens must not obstruct the government in taking any action necessary for the preservation of the integrity and cohesion of the state, for if the state survives, these rights also survive and if the state does not survive, these rights do not survive either.

Typically, rights concerning liberty, freedom of movement, freedom of thought, conscience and speech and freedom of assembly are curtailed during the period of an emergency ${ }^{5}$, for if these rights are allowed to be enjoyed in an unrestrained manner, they might interfere with a government's effort to contain the threat posed to the life of the nation and thereby restore peace. However, experience demonstrates that emergency situations are commonly characterized not only by the suspension of the abovementioned fundamental rights, but also the dispensation of the core fundamental rights, such as the right to life and prohibition on torture ${ }^{6}$. The functioning of the national courts in securing the unhindered enjoyment of the core human rights during emergencies has often been unsatisfactory.

The International Covenant on Civil and Political Rights (ICCPR), 1966, which is the 'most important universal instrument' on human rights with 167 state parties', attempts to strike a balance between protecting national interests and protecting individual rights during an emergency. It empowers states parties to derogate from their obligation to enforce the rights enumerated in the ICCPR during an emergency and consequently subject such derogation regimes to the governance of two substantive principles, i.e. non-derogation and proportionality. ${ }^{8}$ Under Article 40 of the ICCPR, the Human Rights Committee (HRC) is entrusted with the responsibility for ensuring compliance with the abovementioned substantive principles through the review of periodic reports from state parties. ${ }^{9}$ However, the HRC's competence as

$4 \quad$ States of Emergency, p. 413.

$5 \quad$ Fitzpatrick, J. Human Rights in Crisis: The International System for Protecting Rights during States of Emergency. Pennsylvania: University of Pennsylvania Press, 1994, p. 37.

6 Meron, T. Human Rights Law Making in the United Nations: A Critique of Instruments and Process. Oxford: Clarendon Press, 1986, p. 86; Fitzpatrick, J. Human Rights in Crisis: The International System for Protecting Rights during States of Emergency, p. 37.

7 Meron, T. Human Rights Law Making in the United Nations: A Critique of Instruments and Process, p. 83; United Nations Treaty Collection, Chapter IV: Human Rights [interactive]. [accessed on 2010-06-01]. <https://treaties.un.org/Pages/ViewDetails.aspx?mtdsg_no=IV$4 \&$ chapter $=4 \&$ lang $=$ en $>$.

8 International Covenant on Civil and Political Rights (ICCPR) (opened for signature 16 December 1966, entered into force 23 March 1976). 999 UNTS 171. Article 4.

Ibid., Article 40. 
a reporting mechanism has been severely hampered due to substantial delays in the collection of necessary information. For states have often refrained from filing reports under Article 40 altogether ${ }^{10}$ or requested a postponement of the obligation to submit reports during an emergency to evade the responsibility of reporting the measures taken in contravention of the rights enumerated in the ICCPR. ${ }^{11}$ Alternatively, states reports which are actually submitted to the HRC would often contain no relevant information. ${ }^{12}$ Although the HRC can request additional information concerning the derogating measures from states representatives during the review of reports in the form of supplementary reports, such requests have often went unheeded, as well..$^{13}$ Furthermore, reports under Article 40 have also revealed that state parties have either refrained from submitting notices of derogation under Article 4(3) altogether, or submitted such notices 'weeks or even months' after the proclamation of the emergency ${ }^{14}$ or filled notices that were so vague as to make no attempt 'to indicate the nature and scope of the derogations actually resorted to... or to show that such derogations were strictly necessary. ${ }^{15}$ These institutional limitations have also meant that state parties during emergencies have often managed to violate the standards concerning human rights, as enshrined in the ICCPR, with impunity.

Therefore, the weakness of the international treaty based monitoring system requires the implementation of the international standards concerning human rights, such as the principle of non-derogation, within the constitutional framework of every nation. ${ }^{16}$ But the mere incorporation of non-derogable rights within a constitution is not sufficient to prevent their abuse during emergencies. Rather, a list of nonderogable rights should be complemented by the following elaborate mechanisms contained in the constitution for preventing the abuse of rights during declared periods of emergencies:

a) limiting the power to proclaim an emergency to circumstances which truly attain a certain degree of gravity and puts the life of the nation and its subjects under serious risk;

10 See: Report of the Human Rights Committee, Volume 1, 103rd session and 104th session, UN Doc. A/67/40, p. 15-16.

11 McGoldrick, D. The Interface between Public Emergency Powers and International Law. International Journal of Constitutional Law. 2004, 2(2): 391.

12 For instance, the Initial USSR Report, UN Doc. CCPR/C/1/Add.2.

13 McGoldrick, D. The Interface between Public Emergency Powers and International Law. International Journal of Constitutional Law, p. 390; Hartman, J. Derogation from Human Rights Treaties in Public Emergencies. Harvard International Law Journal. 1981, 22(1): 40.

14 Iyer, V. States of Emergency: The Indian Experience. New Delhi: Butterworths, 2000, p. 57.

15 Silva v. Uruguay, Comm. No. 34/1978 (decided on 8 April 1981), in Selected Decisions under the Optional Protocol, UN Doc. CCPR/C/OP/1, para. 8.2.

16 Fitzpatrick, J. Human Rights in Crisis: The International System for Protecting Rights during States of Emergency, p. 77-78. 
b) entrusting the democratically elected legislature, through the device of supermajoritarian escalator (a concept which will be discussed in great detail later on), with the responsibility of ensuring effective scrutiny of a state of emergency; and

c) providing for an overall time limit on the continuation of a state of emergency.

The inclusion of the abovementioned safeguards in a constitution will ensure that the emergencies are not resorted to and continued for imposing arbitrary restrictions on fundamental rights.

In this paper, first, an attempt will be made to examine whether there are any effective mechanisms within the Constitution of Bangladesh, 1972, for preventing abuse of the powers concerning the invocation of emergency and suspension of fundamental rights. Consequently, attention will be turned to the main focus of this article, i.e. the wholesale suspension and the subsequent abuse of the fundamental rights in Bangladesh during emergencies invoked for purposes other than securing the life of the nation. Finally, a number of recommendations will be put forward with a view to ensuring that emergencies can no longer be declared and continued in Bangladesh for extraneous purposes to deprive citizens of their fundamental rights.

\section{The Provisions Concerning Emergency and Suspension of Fundamental Rights in the Constitution of Bangladesh, 1972}

The Constitution of Bangladesh, which was given effect from 16 December $1972,{ }^{17}$ did not originally contain any provision for the declaration of an emergency and, as such, there was no provision in the Constitution concerning the suspension of the enforcement of fundamental rights under any circumstances. Neither did it enact any provision recognising and regulating preventive detention. Perhaps the repeated misuse of the powers of emergency by the Governments of Pakistan (19471971), during the days when Bangladesh (erstwhile East Pakistan) was a province of Pakistan, discouraged the framers of the 1972 Constitution from including in it such powers considering themselves too idealistic. ${ }^{18}$

There was, however, a complete change of mind within only nine months and seven days after the coming into force of the Constitution of Bangladesh, when on 22 September 1973, the Constitution (Second Amendment) Act was passed, which inserted a new Part IXA in the Constitution titled 'Emergency Provisions' (providing for the declaration and continuance of emergency and suspension of enforcement

17 Constitution of Bangladesh, 1972, Article 153(1).

18 As claimed by Mohd Zahirul Islam (Member of Parliament from Chittagong 16) in the Constituent Assembly, Bangladesh. Gonoporishoder Bitorko. Bangladesh Constituent Assembly Debate, Vol. II, 1972, p. 51. 
of the fundamental rights during the period of emergency). In view of the failure of the existing Government to control the rapid deterioration in the economic and law and order situations, such powers were perhaps considered essential to assert itself. ${ }^{19}$

Of the four types of emergency - emergency of war, emergency of subversion, economic emergency and emergency of natural catastrophes - the President of Bangladesh, unlike the Presidents of India and Pakistan ${ }^{20}$, has been given the authority by Article 141A of the Constitution of Bangladesh to declare only two types of emergency, namely, the emergency of war/external aggression and the emergency of internal disturbance. Thus, the notion of emergency in Bangladesh has been kept in its initial security-oriented concept. In order to declare a state of emergency, the Constitution regulates that a 'grave emergency exists in which the security or economic life of Bangladesh, or any part thereof, is threatened by war or external aggression or internal disturbance'. ${ }^{21}$ But clause 3 of Article 141A empowers the President to proclaim an emergency before the actual occurrence of war or external aggression or disturbance if he 'is satisfied that there is imminent danger thereof, which is reproduced from Article 352(3) of the 1949 Indian Constitution. ${ }^{22}$ Hence, responding to an actual crisis has also been supplemented with anticipating an imminent crisis.

It seems that the framers of the Constitution of Bangladesh have failed to limit the power to proclaim a state of emergency solely to circumstances, which capture a certain degree of gravity, putting the life of the nation and its subjects under serious risk, for the Constitution incorporates the imprecise phrase 'internal disturbance', which owes its origin to Colonial legislation ${ }^{23}$ as one of the grounds for declaring an emergency. When a Constitution provides for internal disturbance as a ground for proclaiming an emergency, then what constitutes internal disturbance in a particular case would to a large extent depend upon the personal assessment or judgment of the individual authority concerned.

It should also be stressed here that the Constitution of Bangladesh does not contain any reliable system of checks and balances for overseeing the effective

19 Ahmed, M. Bangladesh: Era of Sheikh Mujibur Rahman. Dhaka: University Press Ltd, 1984, p. 149.

20 Both the Constitutions of India and Pakistan empower their respective heads of states to declare three types of emergency, i.e. emergency of war, emergency of subversion and financial/ economic emergency. See: Constitution of India, 1949, Article 360(1), and Constitution of Pakistan, 1973, Article 235(1).

21 Constitution of Bangladesh, Article 141A(1).

22 The original Clause 3 of Article 352 of the 1949 Indian Constitution has been inserted as the explanatory note to Clause 1 of Article 352 by the Constitution (44th Amendment) Act, 1978.

23 Government of India Act, 1935, in Section 102, empowered the Governor-General of British India to declare that 'a grave emergency exists whereby the security of India is threatened... by... internal disturbance'. 
scrutiny of a state of emergency and its subsequent timely termination. First, the Constitution only requires the proclamation of emergency to be countersigned by the Prime Minister. ${ }^{24}$ However, since pursuant to Article 48(3) of the Constitution, the President, as the ceremonial head of the state, performs all his functions except the appointment of Prime Minister on the advice of the Prime Minister, the requirement of the countersignature of the Prime Minister for securing the validity of the emergency can hardly be considered as a safeguard for preventing any abuse concerning the resort to this power. Rather, this requirement can properly be described as a procedural formality.

Secondly, the Constitution stipulated the requirement of parliamentary endorsement for the continuation of an emergency beyond 120 days. ${ }^{25}$ The requirement of parliamentary approval of an emergency for its continuation beyond 120 days in essence meant that an emergency could continue without any scrutiny for four months. Furthermore, if the Parliament stood dissolved during the continuation of the emergency, then the proclamation of emergency could continue till 'the expiration of thirty days from the date on which Parliament first' met 'after its reconstitution, unless before that expiration of the said period of thirty days a resolution approving the Proclamation' had been passed by the Parliament. ${ }^{26}$ However, the stipulation of parliamentary approval for the continuation of an emergency beyond 120 days has been done away with by the Constitution (Fifteenth Amendment) Act, 2011. Under the new arrangement, the President can now proclaim an emergency for 120 days $^{27}$ and the Parliament has been vested with the sole power to extend the continuation of an emergency beyond 120 days. ${ }^{28}$ But the Amendment Act of 2011 does not incorporate any mechanism in the Constitution for requiring such renewal by the Parliament to be amenable to the approval of a larger majority of lawmakers, making it extremely convenient for the executive to secure such renewal without any difficulty as it commands the support of the majority in the Parliament.

Furthermore, the Constitution of Bangladesh, as amended by the Constitution (Second Amendment) Act, 1973, does not make any attempt to strike a balance between preserving the security of the state and simultaneously protecting individual liberty during an emergency affecting the life of the nation, for the Constitution in Article $141 \mathrm{C}(1)$ has conferred on the President the unfettered power during a state

24 Constitution of Bangladesh, Article $141 \mathrm{~A}(2)$. This provision has been altered by the Constitution (Fifteenth Amendment) Act, 2011.

25 Constitution (Fifteenth Amendment) Act, 2011, Section 41(b).

26 Constitution of Bangladesh, former proviso to Article 141A(2)(c).

27 Ibid., Article 141A(1), as amended by Section 41(a) of the Constitution (Fifteenth Amendment) Act, 2011.

28 Ibid., proviso to Article 141(2)(c), as amended by Section 41(c) of the Constitution (Fifteenth Amendment) Act, 2011. 
of emergency to suspend the enforcement of all or any of the 18 fundamental rights guaranteed by Part 3 of the Constitution.

Although Bangladesh acceded to the ICCPR on 6 September 2000, its Constitution has not been amended to incorporate into it the seven non-derogable rights contained in the ICCPR. The failure of the lawmakers in Bangladesh to amend the Constitution in order to bring it into conformity with the standards concerning human rights as envisaged by the ICCPR has perhaps led to the non-submission of Bangladesh's initial state report, which was due on 6 December 2001, under Article 40 of the ICCPR despite the passing of almost 13 years since accession.

\section{The Exercise of Emergency Powers in Bangladesh and Their Impact on Fundamental Rights}

Since the incorporation of the provisions concerning emergency into the Constitution of Bangladesh on 22 September 1973, emergencies have been proclaimed on five occasions - on 28 December 1974, to concentrate dictatorial powers in the hands of Sheikh Mujibur Rahman and systematically obliterate all opposition to his rule; ${ }^{29}$ on 30 May 1981, following the armed rebellion that involved the assassination of the Head of the State; ${ }^{30}$ on 27 November 1987, to ensure the survival of an autocratic regime; ${ }^{31}$ on 27 November 1990, in a futile attempt to fend off the threats posed to the then dictatorial regime; ${ }^{32}$ and on 11 January 2007, to stage an unprecedented crackdown on the senior leadership of the major political parties, on the ground of internal disturbance. These proclamations of emergency in Bangladesh have witnessed the suspension of fundamental rights on a fairly large scale (i.e. twelve out of eighteen fundamental rights) during four periods and again on a full scale (i.e. suspension of all the eighteen fundamental rights) during the last period (2007-2008). It is worthy of note that all the states of emergency proclaimed

29 Ziring, L. Bangladesh: From Mujib to Ershad: An Interpretive Study. Dhaka: University Press Ltd, 1992, p. 86; Franda, M. Bangladesh: The First Decade. New Delhi: South Asian Publishers, 1982, p. 54; Proclamation of Emergency. Official Gazette. 1974, No. 3 (50)/74-CD (CS); The Constitution (Fourth Amendment) Act, 1975, Sections 15, 23 and 35.

30 Ziring, L. Bangladesh: From Mujib to Ershad: An Interpretive Study, p. 141; 'Assassination of President Zia'. Asian Recorder. 1981, (27): 16099.

31 'Bangladesh: Opposition Leaders Arrested'. Asian Recorder. 1987, 37(52): 19795-19796; Ziring, L. Bangladesh: From Mujib to Ershad: An Interpretive Study, p. 208, 210; 'Bangladesh: Political Stalemate'. Asian Recorder. 1988, 34(13): 19935.

32 Bangladesh Chief Offers Concession to Opposition. The New York Times. 4 December 1990 [interactive]. [accessed on 2013-07-05]. <http://www.nytimes.com/1990/12/04/world/bangladesh-chief-offers-concession-to-opposition.html>; Bangladesh: President Ershad Resigns. Asian Recorder. 1991, 37(2): 21519; Ahmed, S. Bangladesh: Past and Present. New Delhi: S.B. Nangia, A.P.H. Publishing Corporation, 2004, p. 266. 
except that promulgated on 31 May 1981 were unjustified, for the government of the day abused the provisions concerning the invocation of emergency and suspension of fundamental rights as the most effective means for suppressing any opposition to its rule. However, taking into account the severity of abuse in the exercise of emergency powers during the most recent proclamation of emergency (in 2007), in depth discussion will be confined to it only.

\subsection{The Proclamation of Emergency in Bangladesh in January 2007}

When the Government of Bangladesh Nationalist Party (BNP) completed its five year term on 28 October 2006, violent protests, sponsored and led by the Bangladesh Awami League (BAL), broke out in the country over the possibility of the immediate past Chief Justice of the Country, Justice K.M. Hasan heading the Non-Party 'Care-taker' Government. ${ }^{33}$ The BAL alleged that Justice K.M. Hasan, who was constitutionally destined to take over as the Chief Adviser of the Care-taker Government in October 2006 in his capacity as the last retired Chief Justice of the country, was biased to the BNP. ${ }^{34}$

Amidst the violence that had been instigated by the BAL, Justice K.M. Hasan declined to accept the position of the Chief Adviser. The BAL claimed Justice K.M. Hasan's refusal as a victory of its violent agitation. However, without exhausting the four alternative options for appointing the Chief Adviser of the 'Care-taker Government', as laid down in former Article 58C of the Constitution ${ }^{35}$, after Justice K.M. Hasan's reluctance in heading the 'Care-taker' Government, President Iajuddin Ahmed in a dramatic move offered himself as a candidate for assuming the office of the Chief Adviser in addition to the responsibilities of the Presidency probably under provisions of the former Article $58 \mathrm{C}(6)$ of the Constitution of Bangladesh,

33 'Bangladesh Power Shift Postponed'. BBC. 28 October 2006 [interactive]. [accessed on 201307-20]. <http://news.bbc.co.uk/2/hi/south_asia/6093300.stm>. The idea of a Non-Party 'Care-taker' Government was incorporated into the Constitution of Bangladesh through the Constitution (Thirteenth Amendment) Act 1996 due to the distrust that exists between the two main political parties, i.e. the BNP and the BAL, with regard to conducting a free, fair and impartial under the supervision of a political government. It was expected that a Non-Party 'Care-taker' Government, headed by the last retired Chief Justice and 10 Advisers appointed by the President among eminent citizens of the country, due to its neutral character would have no incentive to manipulate the results of the general elections. Constitution of Bangladesh former Articles 58C(1), 58C(2) and (3) and former Article 58D(2) read with Article 123(3). The Chapter on 'Care-taker' Government was repealed from the Constitution of Bangladesh by the Constitutional (Fifteenth Amendment) Act on 3 July 2011. Constitution (Fifteenth Amendment) Act, 2011, Act XIV of 2011, s 21.

34 Bari, M. E. Substantive Independence of Judiciary under the Constitutions of Malaysia and Bangladesh. LLM Thesis, Kuala Lumpur: University of Malaya, 2011, p. 124. 
which empowered the President to take over the position of the Chief Adviser once all options concerning the appointment of the same were exhausted. ${ }^{36} \mathrm{He}$ was able to manage the endorsements of the major political parties except that of the BAL. The BAL's reservation about President Ahmed's neutrality stemmed from the fact that he was elected to the office of the President of the country on a BNP ticket. ${ }^{37}$

Notwithstanding these issues, President Iajuddin assumed the office of the Chief Adviser. But the BAL again took to the streets to stage violent opposition to the Caretaker Government headed by Iajuddin. ${ }^{38}$ It laid down a number of demands, which it felt was necessary for the regime to implement in order to prove its impartiality in holding credible general elections.

But in December 2006, the BAL announced that it would boycott the polls due to the failure of the 'Care-taker' regime of Iajuddin to prove its impartiality and alleged favouritism towards the BNP. ${ }^{39}$ It intensified its violent campaign against the regime with a view to prevent the scheduled elections from taking place on 22 January 2007. The magnitude of the violence coupled with mounting pressure from western diplomats, in particular that of the then US Ambassador and British High Commissioner, Chief of Army Staff along with other senior Army personnel persuaded President Iajuddin on 11 January 2007 to step down from the position of the Chief Adviser ${ }^{40}$ and proclaim an emergency for the fifth time in the history of Bangladesh yet again on the ground of flimsy ground of 'internal disturbance'. ${ }^{41}$

The Presidential Order, which was issued on 11 January 2007 notifying the Proclamation of Emergency, did not make any attempt to encapsulate the persuasive circumstances which constituted the 'internal disturbance'. Rather, the Order merely stated the following: '[a]s it is to the President's satisfaction that a grave emergency exists in which the security or economic life of Bangladesh is threatened by internal disturbance, a Proclamation of Emergency was issued throughout the country until further order under articles $141 \mathrm{~A}(1),(2),(3), 141 \mathrm{~B}, 141 \mathrm{C}(1),(2)$ and (3) of the Constitution'. ${ }^{42}$

Staff Correspondent. President Offers to be Chief Adviser. The Daily Star. 29 October 2006, p. 1. Bangladesh's Controversial Ex-President Iajuddin Ahmed Passes Away. The Times of India. 12 December 2012 [interactive]. [accessed on 2013-08-01]. <http://articles.timesofindia.indiatimes.com/2012-12-10/south-asia/35725921_1_interim-government-bnp-sheikh-hasina>.

Liton, S. President Sworn in as Chief of Caretaker Govt. The Daily Star. 30 October 2006, p. 1. Hasina Declares Tougher Action. The Daily Star. 11 January 2007, p. 1.

Restoring Democracy in Bangladesh (Asia Report No. 151, 2008). International Crisis Group (ICG), 2008, p. 7 [interactive]. [accessed on 2013-07-28]. <http://www.crisisgroup.org/ /media/Files/asia/south-asia/bangladesh/151_restoring_democracy_in_bangladesh>.

Circular Issued by the Office of the President, 11 January 2007.

Ibid. 


\subsubsection{Justification of the Emergency Declared in January 2007}

It seems that the immediate reasons for the declaration of the emergency was the violence resultant of the indefinite strikes invoked by the BAL between October 27 and 11 January 2007 that rendered the economy of the country stagnant. The foreign diplomats saw an intervention by the Army as the only viable option for protecting their developmental 'investments' in the country and, as such, they induced the Army to pressurise Iajuddin in declaring the emergency on 11 January $2007 .{ }^{43}$

The proclamation of emergency was followed by the installation of a new 'Care-taker' Government headed by the former Governor of the Bangladesh Bank, Fakhruddin Ahmed. His appointment as the Chief Adviser, however, was not made after the exhaustion of any of the provisions concerning the appointment of the head of the Care-taker Government as had been enshrined in the Constitution of Bangladesh. The political unrest that was used as a premise to proclaim an emergency conveniently on the ground of 'internal disturbance' on 11 January 2007 came to an end as soon as the new military backed 'Care-taker' regime of Fakhruddin took oath of office. ${ }^{44}$ But despite the cessation of the hostilities which allegedly gave rise to the 'grave emergency', the emergency was nevertheless continued and the parliamentary elections, scheduled to be held on 22 January 2007, were deferred indefinitely. However, as it will be shown below, the emergency was continued beyond its imperative necessities by an unelected interim regime backed by the armed forces for purposes other than that of securing the life of the nation.

First, the new 'Care-taker' regime instead of announcing a timeframe for holding the parliamentary elections sought to undertake a number of policy decisions, which inter alia included reconstitution of the Election Commission and the AntiCorruption Commission, implementation of a voter identification card system, cleansing the prevalent corruption in the politics, separation of the judiciary from the executive ${ }^{45}$, in direct contravention of the provisions concerning the functions of the 'Care-taker' Government as had been enshrined in the Constitution of Bangladesh, for the Constitution of Bangladesh stipulated that the 'Care-taker' regime would only carry on 'the routine functions of such government' and 'not make any policy decision' ${ }^{46}$ Its principal constitutional mandate was to provide necessary assistance to the Election Commission in 'holding the general election of members of parliament

43 ICG, p. 9.

44 Grand Alliance Calls off All Programmes. The Daily Star. 13 January 2007, p. 1 [interactive]. [accessed on 2013-05-05]. <http://archive.thedailystar.net/2007/01/13/d7011301096.htm>.

45 CA Vows to Transfer Power through Polls at Earliest, EC to be Reconstituted, Flawless Electoral Roll to be Prepared. The Daily Star. 22 January 2007, p. 1; Jahangir, J. Bangladesh's Fresh Start. Journal of Democracy. 2009, 20: 49. 
peacefully, fairly and impartially' within 90 days of the dissolution of the Parliament ${ }^{47}$. Thus, it seems that the continuation of the emergency was considered a necessity by the military backed 'Care-taker' regime for sustaining the facade of its 'Care-taker' tag, as the Emergency Powers Ordinance made it a well-nigh impossibility to challenge any action of the regime taken in 'good faith' for preserving the 'interests of the state and the population' ${ }^{48}$ in any court of law. ${ }^{49}$ In other words, the emergency enabled the regime to justify its policy decisions by claiming that such policy decisions were necessary in the very interests of the state and the population, and as such, they were not amenable to review by any court of law. Therefore, in essence, the regime felt it necessary to continue the emergency with a view to use it as a shield against any challenge to its constitutionality.

Secondly, the continuance of the emergency was considered a necessary evil by the military backed regime for crushing the two mainstream political parties of the country. The Chief of Army, General Moeen U Ahmed, in a speech on 3 April 2007 signalled the possibility of the rise of a third political force rather than a return to the status quo, when he stated the following:

The roadmap to democracy lies, I presume, with objectives as envisioned by the government... within [an] affordable time frame that will steer the country away from escapism and build [a] strong foundation of validity on democracy... We do not want to go back to an elective democracy where corruption in society becomes all pervasive, governance suffers in terms of insecurity and violation of rights, and where political criminalisation threatens the very survival and integrity of the state..$^{50}$

The above observations of the Army Chief brought to the fore the fear that Bangladesh was perhaps sliding towards a formal military rule following in the footsteps of Pakistan, for in Pakistan General Parvez Musharraf had ascended to power through the proclamation of an emergency in 1999. Consequently, Musharraf used the emergency as an instrument to systematically annihilate the political parties on charges of corruption and send the leaders of two major political parties, i.e. Benazir Bhutto and Nawaz Sharif, to exile. ${ }^{51}$

Ibid., in former Article 58D(2) read together with Article 123(3).

Ibid, second preambular para.

The Emergency Powers Ordinance. Official Gazette. 2007, S.R.O. No. 15-Law/2007, s 6(2).

Bangladesh to Have Own Brand of Democracy. The Daily Star. 3 April 2007, p. 1.

Gall, C. Bhutto Announces Date of Return to Pakistan. The New York Times. 15 September 2007 [interactive]. [accessed on 2013-06-08]. <http://www.nytimes.com/2007/09/15/world/ asia/15pakistan.html?ref=pervezmusharraf $>$; Gall, C. Pakistan Edgy as Ex-Premier Is Exiled Again. The New York Times. 11 September 2007 [interactive]. [accessed on 2013-06-08]. $<$ http://www.nytimes.com/2007/09/11/world/asia/11 pakistan.html?ref=pervezmusharraf\&_ $\mathrm{r}=0>$. 
This fear gained further momentum when the military backed 'Care-taker' regime sought to implement the 'minus-two' formula. The formula involved sending the leaders of BNP and Awami League, i.e. Begum Khaleda Zia and Sheikh Hasina, to exile. It was announced by the regime in mid-April that Begum Zia would be sent to Saudi Arabia, while Sheikh Hasina, who had went to USA on a family visit, would not be allowed to return to the country. ${ }^{52}$ Furthermore, with a view to prevent Hasina from re-entering the country, the regime filed cases implicating her for the deaths that had occurred during the political unrest between October 2006 and January 2007.53

\subsubsection{Impact of the Proclamation of Emergency, 2007, on the Fundamental Rights}

Taking the advantage of the lacuna of the Constitution which does not provide any guidelines as to which of the 18 fundamental rights should remain stalwart in the face of a declared emergency, the President, following the proclamation of the emergency on 11 January 2007, issued an order suspending the rights of the citizens to move any court for the enforcement of all the 18 fundamental rights guaranteed by the Constitution of Bangladesh. ${ }^{54}$ This is an unprecedented event in the history of the emergency regimes in Bangladesh as all the previous four emergency regimes established the pattern of suspending the enforcement of only 12 of the 18 fundamental rights. It should be stressed here that only fundamental rights, such as freedom of movement, freedom of assembly, freedom of association, freedom of speech, etc., which if enjoyed in an unrestrained manner might have created difficulties in the way of re-establishing peace, and, as such, deserved suspension only for so long as is absolutely necessary. It also seems that the emergency regime did not take into account the fact that Bangladesh acceded to the 1966 ICCPR in September 2000, which required it to be respectful to the non-derogable rights as enshrined in the Covenant and suspend only those rights which had a direct bearing on the emergency. Furthermore, the government in fulfilment of Bangladesh's obligation as a state party to the ICCPR was required to immediately notify under Article 4(3) the UN Secretary-General of its intention to derogate from the provisions of the Covenant and reasons for the derogation. Neither such a notice was ever filled by the emergency regime, nor was there any request from the UN Secretary-General's Office or the Human Rights Committee asking Bangladesh Government to fulfil its obligation under the Covenant.

Due to the absence of any effective mechanisms within the Constitution of Bangladesh for scrutinising the executive actions during a state of emergency, many

52 Bangladesh: The Minus-Two Solution. The Economist. 8 September 2007, p. 66.

53 Fair, C. On the Issues: Bangladesh. Washington DC: United States of Institute of Peace, 27 April 2007, p. 1.

54 Emergency Power Ordinance, 2007, Article 5(1). 
of the suspended rights were grossly abused with impunity. An attempt will now be made to briefly underscore some of these abuses.

\subsection{Arbitrary and Unlawful Deprivation of Right to Life}

The Constitution of Bangladesh, 1972, as pointed out earlier, guarantees the right to life in Article 32 as a fundamental right. But taking benefit of the suspension of the enforcement of this right along with the other rights guaranteed by the Constitution following the imposition of the emergency on 11 January 2007, as many as 315 persons were killed extra-judicially by the law enforcement agencies during the continuation of the emergency for nearly two years. ${ }^{55}$ The emergency regime, however, labelled these killings as 'crossfire killings', 'gunfights' or 'encounter killings' ${ }^{56}$ in an attempt to imply that these persons were members of criminal groups who were engaged in exchanges of gunfire with the law enforcement agencies.

The official version of the cover-up of these killings was very much in line with the spirit of the Emergency Powers Ordinance, 2007, which in S. 6(1) provided that 'no action, done by a person in good faith, according to this ordinance or any rule under this Ordinance or any provision under such rule, may be challenged in civil or criminal court'.

\subsection{Arbitrary Arrests}

In pursuance of S. 3 of the Emergency Powers Ordinance, 2007, the government framed the Emergency Power Rules on 25 January 2007, which in Rule 16(2) empowered the law enforcement agencies to 'arrest without warrant and take legal actions against any person'. Furthermore, the Emergency Power Rules in Rule 19D took away the right of a detainee to apply for bail. Consequently, an astounding 500 thousand individuals were arbitrary arrested during the continuance of the emergency. ${ }^{57}$ The Inspector General of Police told the media on 9 June 2008 that since the proclamation of the emergency an average of 1,667 persons were being arrested every day. He further admitted that these arrests were deliberately placed under the Emergency Power Rules with a view to preclude the authority of courts to release the suspects on bail. ${ }^{58}$

Thus, it seems that the trend of arbitrarily arresting a striking number of individuals every day, even when the alleged hostilities, which gave rise to the

55 Asian Human Rights Commission. The State of Human Rights in Bangladesh, 2008, AHRCSPR-008-2008, p. 30.

56 World Organisation against Torture. Severe Human Rights Violations under the Sate of Emergency. 15 February 2008 [interactive]. [accessed on 07-07-2013]. <http://www.refworld.org/ docid/47d79677c.html>.

57 Asian Human Rights Commission, p. 23.

58 Asian Human Rights Commission, p. 24. 
emergency, ceased to exist was continued with a view to perpetuate the rule of the military backed 'Care-taker' regime at the expense of one of the most fundamental rights of individuals - the right to liberty. Furthermore, these arrests took place notwithstanding the fact that the prisons in Bangladesh did not have enough space to accommodate so many persons. In other words, the arrest of 500 thousand persons by the law enforcing agencies was more than 1478.24 per cent of the official capacity of the prisons in Bangladesh, which is $33,824 .^{59}$

\subsection{Torture and Cruel or Inhuman or Degrading Treatment}

The Constitution of Bangladesh in Article 35(5) prohibits 'torture or cruel, inhuman, or degrading' treatment. But the suspension of the enforcement of all the fundamental rights allowed the military backed emergency regime to use various methods of torture as the most effective means of coercing false confessions of guilt from the politicians belonging to the two major political parties with a view to bar them from contesting in the next general elections and thereby implement its political agenda of staying in power indefinitely.

The most common methods of torture used by the law enforcement agencies in the various torture cells operated by them were the following ones:

a) hanging persons from the ceiling by their wrists and consequently beating them up mercilessly;

b) electric shocks;

c) pouring very hot water over the victim's head with a view to scald it; and

d) insertion of 'nails or needles under the fingernails or toenails or other sensitive parts of the body' ${ }^{60}$

Thus, the emergency regime tortured detainees in disregard of Bangladesh's obligations under the ICCPR ${ }^{61}$, which it acceded in 2000, and the Convention against Torture and Other Cruel, Inhuman or Degrading Treatment or Punishment ${ }^{62}$, which it acceded in 1998, to protect its citizens from custodial torture and cruel treatment.

59 International Centre for Prison Studies. World Prison Brief: Bangladesh [interactive]. [accessed on 2014-03-10]. <http://www.prisonstudies.org/country/bangladesh $>$.

60 Asian Human Rights Commission, p. 25.

61 ICCPR in Article 4(2) makes the right not to be subjected to torture or to cruel, inhuman or degrading treatment or punishment non-derogable.

62 Convention against Torture and Other Cruel, Inhuman, or Degrading Treatment or Punishment, (adopted 10 December 1984, entered into force 26 June 1987). UN Doc. A/Res/39/46 (1984), Article 2(2). 


\subsubsection{The Challenge to the Constitutionality of the 2007 Emergency and the Eventual Termination of the Emergency}

In July 2008, for the first time in the history of emergency regimes in Bangladesh, the constitutionality of the emergency proclaimed on 11 January 2007 and the consequent suspension of all the fundamental rights were challenged after more than one and a half years of its continuation in M. Saleem Ullah and Others $v$ Bangladesh ${ }^{63}$. The High Court Division of the Supreme Court of Bangladesh after an initial hearing issued a rule nisi demanding an explanation from the military backed regime as to why the emergency declared on 11 January 2007 and the restrictions on fundamental rights should not be declared unconstitutional. The Court also asked the regime to provide its roadmap and timeframe for handing over power to a government elected through free, fair and credible general elections.

The military had by this time come to the realisation that its aspiration of formally taking the helm of the country through the imposition of a possible martial law could not be materialised, for the foreign dignitaries, who had once encouraged them to play a leading role in ending the political stalemate in the country, had now signalled their unwillingness to support a formal military take over. The diplomats felt that while the initial intervention by the Army was necessary, the systematic slide towards formal military rule by annihilation of the politicians and the curtailment of all the fundamental rights of individuals had the impact of further undermining their developmental investments in Bangladesh. ${ }^{64}$

Consequently, before the High Court Division could decide in detail the merits of the challenge to the invocation of the emergency, the state of emergency and restrictions on the fundamental rights after nearly two years of continuation were ultimately lifted on 17 December $2008^{65}$, rendering the case instituted in July 2008 challenging their constitutionality inoperative.

The foregoing discussion reveals that the political impasse between October 2006 and January 2007 required a political solution. This is evident from the fact the political unrest came to an end as soon as the new 'Care-taker' regime was installed. Therefore, it goes without saying that the emergency was invoked and continued for political purposes rather than for securing the life of the nation and, as such, it cannot at all be justified.

63 The Supreme Court of Bangladesh, High Court Division, Writ Petition No. 5033 (2008) [unreported].

64 ICG, p. 7.

65 Liton, S. Emergency Out, Rights In. The Daily Star. 17 December 2008, p. 1. 


\section{Conclusions and Recommendations}

The most recent abuse of the power to invoke emergency, arbitrary suspension of the enforcement of all the fundamental rights and the continuation of these extraordinary measures beyond their imperative necessities have brought to the fore the necessity of the incorporation of the following reforms within the Constitution of Bangladesh, 1972:

a) The Constitution of Bangladesh, 1973, as pointed out earlier in section 2 of this Article, empowers the President to proclaim a state of emergency on the grounds war or external aggression or internal disturbance. While both war and external aggression carry precise connotations, the phrase internal disturbance, as pointed earlier in section 2, is imprecise in nature and consequently has conveniently facilitated all the five proclamations of emergency in Bangladesh, including the emergency of 2007.

Thus, this basis (internal disturbance) should be replaced with 'armed rebellion' by an amendment to the Constitution of Bangladesh, as it has been done in the case of the Indian Constitution by the Constitution (FortyFourth Amendment) Act, 1978, for 'armed rebellion' as opposed to internal disturbance carries a precise connotation. ${ }^{66}$ An emergency on the ground of 'armed rebellion' can only be declared when hostilities between the governmental and non-governmental forces attain a certain level of intensity, for instance, when due to the nature of hostilities the government is induced to deploy military forces against the rebels instead of the ordinary law enforcing agencies, i.e. the police forces. ${ }^{67}$

The confinement of the power to proclaim emergency under the Constitution of Bangladesh to clearly defined circumstances can go a long way to obviate the possibility of any abuse of the power to resort to such an extraordinary measure to deprive citizens of their fundamental rights.

b) The absence of a provision in the Constitution of Bangladesh, 1972, for the termination of emergency as soon as the circumstances which gave rise to it are adequately contained, has provided the executive with significant leeway to take steps towards the institutionalisation of the emergency at the expense of the fundamental rights of the citizens. Thus, a proclamation of emergency under Article 141A of the Constitution of Bangladesh should be subject to a prompt ratification of the Parliament within 14 days from such proclamation. Furthermore, a provision for the unhindered continuation of the legislature during a state of emergency should be inserted in the Constitution in order to invest it with the responsibility of not only ratifying the 
proclamation of emergency, but also ensuring that it does not continue beyond the cessation of the hostilities which gave rise to it.

After the initial ratification, the proclamation of emergency should be subjected to periodic review by the Parliament. However, it should be stressed here that such an arrangement may lose its efficacy if the party in power has the support of the requisite number of members in the Parliament. Therefore, the Constitution of Bangladesh should provide for stricter guidelines with regard to the extension of the proclamation of the emergency by the Parliament. In this context, the idea of incorporating the device of 'supermajoritarian escalator', as put forward by Bruce Ackerman and discussed below, may be resorted to.

Ackerman, being influenced by the Constitution of South Africa ${ }^{68}$, proposed a model, coined as the 'supermajoritarian escalator model', on which a proclamation of emergency should be placed before the legislature for its endorsement within 14 days and thereafter be subjected to repeated renewals every two months, requiring each such renewal to be amenable to the approval of a larger majority of legislators -60 percent for the first two months, 70 percent for the next two months and 80 percent for each subsequent two month intervals. ${ }^{69}$ The advantage of the 'supermajoritarian escalator model' is that it not only contributes towards the timely revocation of emergency powers, but it also acts as an effective check on any potential abuse of emergency of powers.

But the 'supermajoritarian escalator' model, as developed by Ackerman, is not free from deficiencies. In the first place, his version of the 'supermajoritarian escalator' can be best described as a weak version of the model, for he sets the first escalating cascade of supermajority at only 60 percent, which does not even constitute two-thirds of the total members of the legislature and the difference between a simple majority and 60 percent is too narrow and, as such, can be masterminded by the executive by persuading the legislators belonging to smaller parties and independent legislators to vote in favour of the extension of the proclamation. The executive can influence the support of such members by painting a grim picture of the threats looming over the nation.

Secondly, Ackerman's 'supermajoritarian model' does not envisage a maximum period of emergency. Rather, it relies entirely on the legislators to bring an end to the emergency proclaimed.

The abovementioned predicaments, therefore, suggest the incorporation within the Constitutional framework of Bangladesh of a stronger version

69 Ackerman, B. Before the Next Attack: Preserving Civil Liberties in an Age of Terrorism. Connecticut: Yale University Press, 2006, p. 80. 
of the 'supermajoritarian escalator', requiring the issue of the renewal of a proclamation of emergency after the first two months to be approved by two-thirds (66.66 \%) of the total number of members of the legislature. The subsequent escalator due for the continuation of emergency beyond four months should require the support of three-quarters (75\%) of the legislators. Since the objective of the 'supermajoritarian escalator' is to prevent the executive attempting to stretch an emergency beyond its absolute necessity by making it easy for a small minority of legislators to oversee the timely termination of the emergency, it can strongly be argued that only a strong version of the 'supermajoritarian model' can attain such an objective.

c) Regarding the question as to the fate of a proclamation of emergency after receiving the assent of the three-quarters of the legislators for continuation beyond four months, the Constitution of Bangladesh should fix the maximum period of emergency at six months. Thus, a proclamation of emergency after securing two extensions from the pre-requisite supermajorities of the Parliament must come to an end on the completion of six months. ${ }^{70}$ Prescribing a time limit on the continuation of the emergency provides notice to everyone concerned that the executive cannot manipulate the continuation of an emergency for political purposes beyond the six-month period to impose long-lasting restrictions on the fundamental rights of the citizens.

d) Article $141 \mathrm{C}$ of the Bangladesh Constitution should be amended to incorporate into it the seven non-derogable rights contained in the 1966 ICCPR (which Bangladesh acceded in September 2000) that are deemed to be too precious to be suspended during the period of emergency. The enumeration of non-derogable rights in the Constitution of Bangladesh, complemented by the abovementioned safeguards, will ensure fewer human rights breaches during a state of emergency.

Thus, if the Constitution of Bangladesh is amended ${ }^{71}$ to incorporate into it the emergency model devised above, providing for legal limits on the power of the executive as to the proclamation, administration and termination of emergency, then it would not only reduce the possibility of the abuse of the emergency powers, but also ensure the maintenance of rule of law, in which it is the law that governs through the instrumentality of man, and not the man independently of or above the law.

70 States of Emergency, p. 459. If the threat posed to the life of the nation continues for more than six months, it nevertheless remains open to the executive to proclaim a fresh emergency. The principal objective is to ensure that executive action is governable by the rule of law.

71 Constitution of Bangladesh in Article 142(1)(a) states that any proposed bill for amendment to the Constitution can be passed by the votes of 'two-thirds of the total number of members of the Parliament'. 


\section{References}

Ackerman, B. Before the Next Attack: Preserving Civil Liberties in an Age of Terrorism. Connecticut: Yale University Press, 2006.

Ahmed, M. Bangladesh: Era of Sheikh Mujibur Rahman. Dhaka: University Press Ltd, 1984.

Bari, M. E. Substantive Independence of Judiciary under the Constitutions of Malaysia and Bangladesh. LLM Thesis, Kuala Lumpur: University of Malaya, 2011.

Bonner, D. Emergency Powers in Peacetime. London: Sweet \& Maxwell, 1985.

Case IT-94-1-A, [1995] ICTY.

Case IT-03-66-T, The Prosecutor $v$. Fatmir Limaj, [2005] ICTY.

Convention against Torture and Other Cruel, Inhuman, or Degrading Treatment or Punishment (adopted 10 December 1984, entered into force 26 June 1987). UN Doc. A/Res/39/46 (1984).

Constitution of Bangladesh, 1972.

Constitution of India, 1949.

Constitution of Pakistan, 1973.

Constitution of South Africa, 1996.

Fitzpatrick, J. Human Rights in Crisis: The International System for Protecting Rights during States of Emergency. Pennsylvania: University of Pennsylvania Press, 1994.

Franda, M. Bangladesh: The First Decade. New Delhi: South Asian Publishers, 1982.

Government of India Act, 1935.

Hartman, J. Derogation from Human Rights Treaties in Public Emergencies.
Harvard International Law Journal. 1981, 22(1).

International Covenant on Civil and Political Rights (ICCPR) (opened for signature 16 December 1966, entered into force 23 March 1976). 999 UNTS 171.

Iyer, V. States of Emergency: The Indian Experience. New Delhi: Butterworths, 2000.

Jahangir, J. Bangladesh's Fresh Start. Journal of Democracy. 2009, 20.

Meron, T. Human Rights Law Making in the United Nations: A Critique of Instruments and Process. Oxford: Clarendon Press, 1986.

McGoldrick, D. The Interface between Public Emergency Powers and International Law. International Journal of Constitutional Law. 2004, 2(2).

Report of the Human Rights Committee, Volume 1, 103rd session and 104th session, UN Doc. A/67/40.

Rossiter, C. Constitutional Dictatorship: Crisis Government in the Modern Democracies. New Jersey: Princeton University Press, 1948.

Silva v. Uruguay, Comm. No. 34/1978 (decided on 8 April 1981), in Selected Decisions under the Optional Protocol, UN Doc. CCPR/C/OP/1.

States of Emergency - Their Impact on Human Rights: A Comparative Study by the International Commission of Jurists. Geneva: International Commission of Jurists.

The Supreme Court of Bangladesh, High Court Division, Writ Petition No. 5033 (2008) [unreported]. 
United Nations Treaty Collection, Chapter IV: Human Rights [interactive]. [accessed on 2010-0601]. <https://treaties.un.org/Pages/ ViewDetails.aspx?mtdsg_no=IV-4\& chapter $=4 \&$ lang $=$ en $>$.

\section{NETEISĖTO NAUDOJIMOSI NEPAPRASTOSIOS PADĖTIES REŽIMU IR JO POVEIKIO FUNDAMENTALIOSIOMS TEISĖMS BANGLADEŠE KRITINIS VERTINIMAS} Ershad: An Interpretive Study. Dhaka: University Press Ltd, 1992.

M. Ehteshamul Bari

Macquarie universitetas, Australija

Anotacija. Nepaprastosios padèties juvedimas gali būti teisètas konstitucinis metodas taikyti ivairias priemones siekiant apsaugoti visuomenés interesus valstybëje kylant kriziu grèsmei. Vis dèlto toks režimas riboja žmogaus teisiu igyvendinima, tad jis turètu büti taikomas ypatingai atsakingai. Straipsnyje analizuojama, ar teisèti buvo Bangladešo žmoniu teisiu apribojimai kovojant su "vidiniais neramumais“. Šiame darbe identifikuojama, kad Bangladešo konstitucijoje nèra ịtvirtinto efektyvaus mechanizmo, užkardančio piktnaudžiavima šia procedūra, kas sudaro prielaidas nepaprastaja padèti taikyti kitais, nei ji yra skirta, sumetimais.

Reikšminiai žodžiai: nepaprastoji padètis, fundamentaliųu teisiu ribojimas, teisinè valstybé.

\section{THE UNJUST EXERCISE OF EMERGENCY POWERS IN BANGLADESH AND THEIR CONSEQUENT IMPACT ON THE FUNDAMENTAL RIGHTS: A CRITICAL APPRAISAL}

M. Ehteshamul Bari

Macquarie University, Australia

Summary. The declaration of a state of emergency can be a legitimate constitutional method to take prompt measures in protecting the interests of the society in times of crises threatening the life of the nation. But as it entails restrictions on the fundamental rights of the citizens, it must be used with utmost care and as a means of last resort only. The objective of this paper is to examine whether it has been justifiable 
to deprive the citizens of Bangladesh from the enjoyment of all or majority of the 18 fundamental rights guaranteed by the Constitution during the continuance of the five emergencies invoked for dealing with 'internal disturbance'. In this paper, it has been found out that in the absence of effective mechanisms in the Constitution of Bangladesh to obviate the possibility of abuse of the procedure for invoking and clinging on to emergency powers, emergencies have been conveniently resorted to and continued by succeeding generations of executive for purposes other than that of securing the life of the nation at the expense of the core fundamental rights of individuals. Therefore, this paper recommends for insertion of the following safeguards in the Constitution of Bangladesh for not only reducing the possibility of abuse of the emergency powers, but also ensuring the maintenance of the rule of law: a) a list of concrete circumstances which truly endanger the life of the nation and thereby merit the proclamation of a state of emergency, $b$ ) the mechanisms for ensuring the effective scrutiny of a state of emergency and its timely termination, and c) a list of non-derogable rights to prevent the abuse of human rights.

Keywords: state of emergency, suspension of fundamental rights, rule of law.

M. Ehteshamul Bari, Macquire universiteto Teisès mokyklos doktorantas ir dèstytojas. Mokslinių tyrimų kryptys: konstitucinė teisė, žmogaus teisės, viešoji tarptautinè teisè.

M. Ehteshamul Bari, Macquarie Law School, Macquarie University, NSW 2109, Australia, $\mathrm{PhD}$ Candidate and Sessional Academic. Research interests: constitutional law, human rights, public international law. 